\title{
The NIST Impact Test Facility
}

Harry W. Shenton III

Erik D. Anderson

John L. Gross

Richard D. Marshall

Building and Fire Research Laboratory

Gaithersburg, Maryland 20899

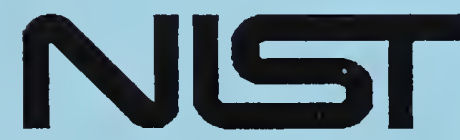

United States Department of Commerce

Technology Administration

National Institute of Standards and Technology 


\section{The NIST Impact Test Facility}

Harry W. Shenton III

Erik D. Anderson

John L. Gross

Richard D. Marshall

January, 1992

Building and Fire Research Laboratory

National Institute of Standards and Technology

Gaithersburg, MD 20899

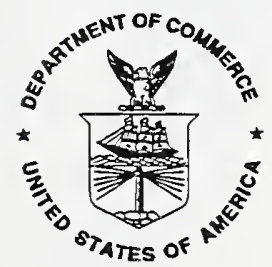

U.S. Department of Commerce

Barbara Hackman Franklin, Secretary

Technology Administration

Robert M. White, Under Secretary for Technology

National Institute of Standards and Technology

John W. Lyons, Director 



\begin{abstract}
The National Institute of Standards and Technology has recently constructed an Impact Test Facility (ITF), which is to be used in the investigation of the behavior of structural elements and systems subject to loads of short duration and high intensity. The ITF consists of a $21.9 \mathrm{~m}$ vertical drop tower and free-fall impactor. A peak impact velocity of $17 \mathrm{~m} / \mathrm{s}$ can be attained in the ITF with a full-height drop, delivering $8,500 \mathrm{~N}$-m of kinetic energy to a specimen using a $59 \mathrm{~kg}$ impact sled. The components of the system include the vertical drop tower, impact sled, sled hoist assembly, sled fall arresting system, specimen support frame, instrumentation and data acquisition system. The system has been designed to be versatile and can be adapted to meet a wide variety of test requirements.
\end{abstract}



Table of Contents

Page

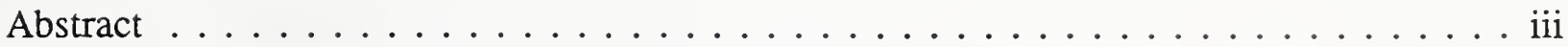



1.1 General Description . . . . . . . . . . . . . . . . 2

2. Impact Test Facility Components . . . . . . . . . . . . . . 4



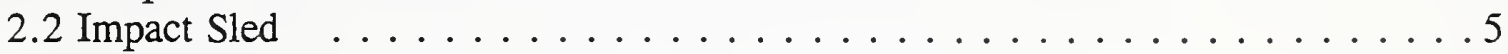

2.3 Sled Hoist Assembly . . . . . . . . . . . . . . . . . . . 5

2.4 Sled Fall Arresting System . . . . . . . . . . . . . . 6

2.5 Specimen Support Frame . . . . . . . . . . . . . . . . . . 6

2.6 Instrumentation and Data Acquisition $\ldots \ldots \ldots \ldots \ldots$

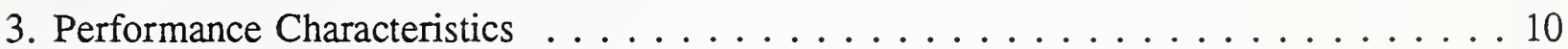



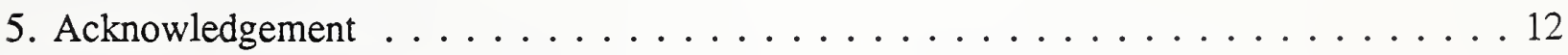

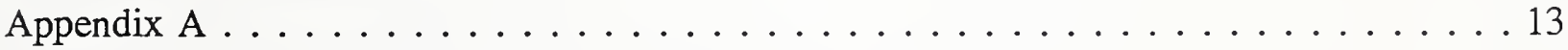



Figure 1.

Figure $1 . \quad$ NIST Impact Test Facility $\ldots \ldots \ldots \ldots \ldots \ldots \ldots \ldots$

Figure 2. Impact sled and sled hoist assembly $\ldots \ldots \ldots \ldots$

Figure 3. Specimen support frame and sled fall arresting system . . . . . . . . 8

Figure $4 . \quad$ Velocity calibration curve $\ldots \ldots \ldots \ldots \ldots \ldots \ldots$

Figure A.1 Drop tower assembled on laboratory floor prior to erection . . . . . . . 13

Figure A.2 During erection; lifting third " $\mathrm{H}$ " section into place . . . . . . . . 14

Figure A.3 During erection; bolting third " $\mathrm{H}$ " section into place . . . . . . . . . . 14

Figure A.4 Drop tower and specimen support frame $\ldots \ldots \ldots \ldots \ldots$

Figure A.5 Drop tower, specimen support frame and impact sled . . . . . . . 16

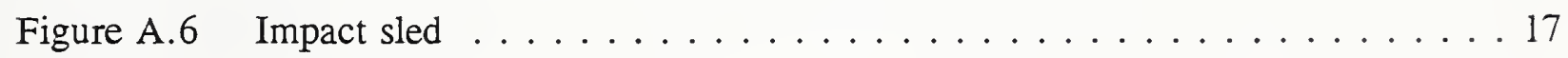

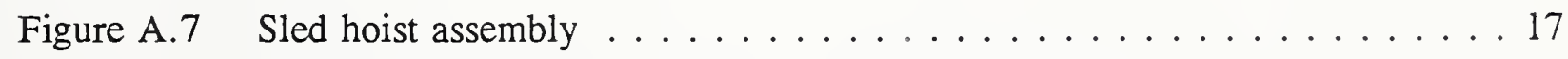

Figure A.8 Tup assembly with load cells $\ldots \ldots \ldots \ldots \ldots \ldots$

Figure A.9 Simple-support reaction fixture $\ldots \ldots \ldots \ldots \ldots \ldots$

Figure A.10 Sled fall arresting system . . . . . . . . . . . . . 19

Figure A.11 Data acquisition system . . . . . . . . . . . . . . 19 

List of Tables

Page

Table 1. Experimental (Average of 2 Drops) and Theoretical Velocity of Sled $1.94 \mathrm{~m}(6.35 \mathrm{ft})$ Above Ground. . . . . . . . . . . . . 10 



\section{Introduction}

The Building and Fire Research Laboratory (BFRL) of the National Institute of Standards and Technology (NIST) has recently constructed an Impact Test Facility (ITF). The purpose of this facility is to investigate the behavior of structural components and assemblies subject to loads of short duration and high intensity. The facility consists of a vertical drop tower, sledmounted impactor, sled hoist assembly, sled fall arresting system, specimen support frame, instrumentation, and data acquisition system.

The facility is currently being used to evaluate the fracture characteristics of fiberglassreinforced epoxy tubes to be used by the Federal Aviation Administration in landing aid support structures. These structures would typically be located around airport runways and would support navigational aides, approach lights and other electronic equipment. The goal of this research is to develop structural systems that will withstand all normal operational loads associated with airport structures, yet break apart with minimal effort upon accidental impact by a light aircraft.

\subsection{General Description}

The Impact Test Facility is located in the Large Scale Structures Laboratory of the BFRL at NIST. A simple schematic of the ITF is presented in Figure 1.

In a typical impact test, a specimen is mounted horizontally in the support frame and placed in the fall line of the impactor. The impact sled, which carries the tup (i.e., the impact head or surface) and instrumentation, is raised to a prescribed elevation and released. The impact sled then falls freely under its own weight and strikes the test specimen. The sled is arrested at ground level using deformable foam bumpers.

The drop tower columns form the "rail" or "guide" in which the impact sled travels. The impact sled can be raised to any elevation above the laboratory floor, to a maximum height of $18.3 \mathrm{~m}(60 \mathrm{ft})$. Thus a range of impact velocities are possible, up to a theoretical maximum of $18.9 \mathrm{~m} / \mathrm{s}(62 \mathrm{ft} / \mathrm{s})$. Taking into account frictional losses and the distance required to stop the sled, the actual peak impact velocity is approximately $16.7 \mathrm{~m} / \mathrm{s}(55 \mathrm{ft} / \mathrm{s}$ or $32 \mathrm{knots})$. The current impact sled is nominally $1.1 \mathrm{~m}(3.5 \mathrm{ft})$ wide; however, the drop tower can be adjusted to accommodate sleds of width 0.46 to $1.60 \mathrm{~m}(1.5$ to $5.25 \mathrm{ft})$. The sled is conveniently raised to the desired elevation using a cable and winch system, and released from ground level by an electronic switch.

As currently configured, the specimen support frame is primarily intended for use with beam type specimens. The frame can support specimens ranging in length from $0.61 \mathrm{~m}(2 \mathrm{ft})$ to $3.66 \mathrm{~m}(12 \mathrm{ft})$, and as wide as the impact sled. The test specimen can be set-up in a simply- 



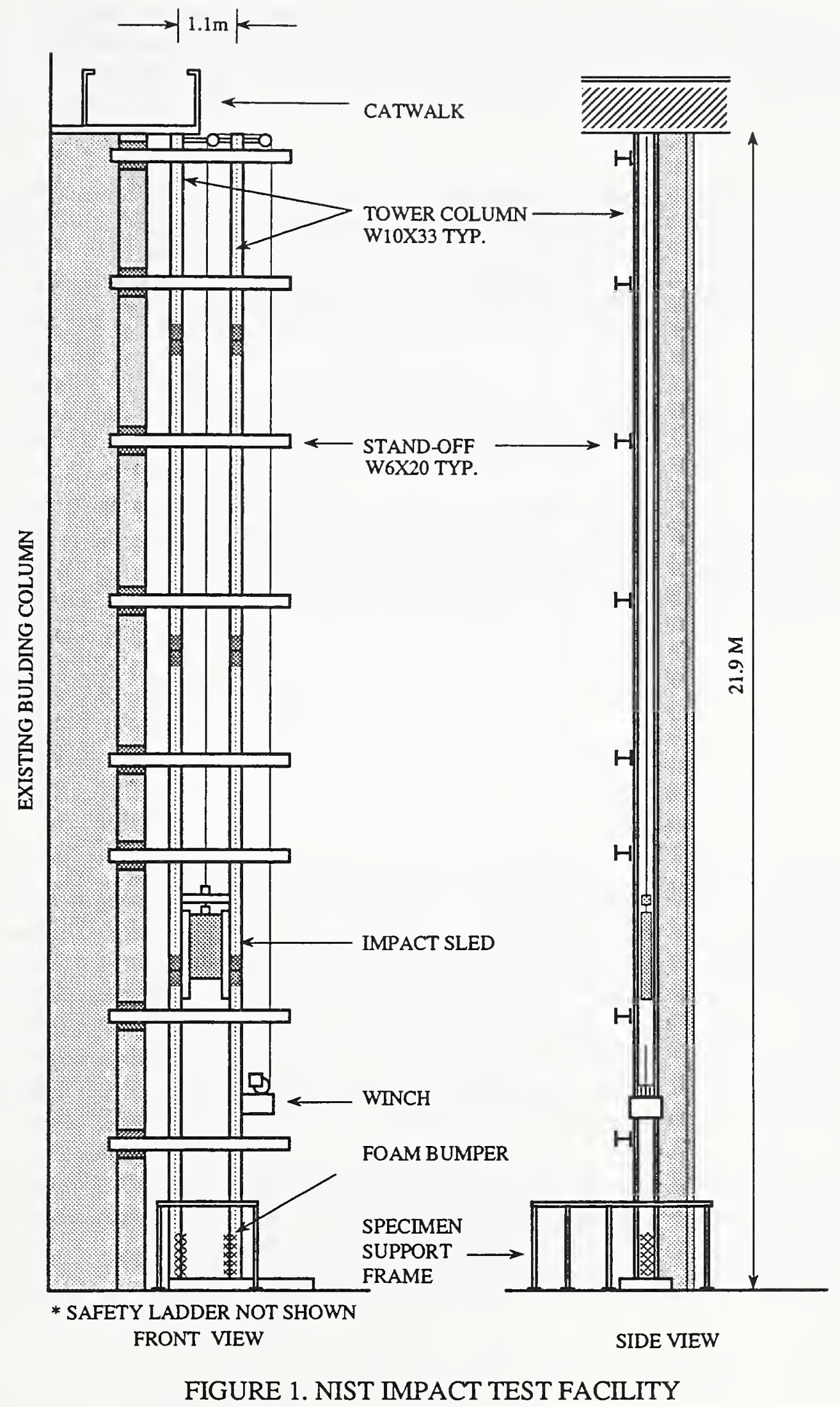



supported, clamped, or cantilevered configuration. Axial compressive and tensile loads can be applied to the specimen in a pin-ended configuration. Although the support frame was designed primarily for beam specimens, it is modular and can be configured for other applications. Alternatively, the support frame can be disassembled and removed and other fixtures designed as needed.

Instrumentation currently includes an accelerometer mounted on the impact sled, and two piezoelectric load cells and an accelerometer in the tup to measure the dynamic impact load and acceleration at the point of impact. An optical switch with a translucent grid is also used to measure the displacement of the sled during the early phase of impact. In the simply-supported configuration a single specimen reaction is measured using two piezoelectric load cells mounted to the support frame.

Data is recorded using a 128 channel digital data acquisition system. The system has a maximum sampling rate of 250,000 samples per second, gross, over all data channels.

The remainder of this report is devoted to a more detailed discussion of the NIST Impact Test Facility. Section 2 discusses the components of the facility in more detail. Section 3 discusses the performance characteristics of the facility. Presented in Appendix A are a number of photographs of the drop tower under construction and the various components of the facility.

\section{Impact Test Facility Components}

\subsection{Drop Tower}

\section{$\underline{\text { Design }}$}

The vertical drop tower consists of two $21.9 \mathrm{~m}$ ( $72 \mathrm{ft}$ ) steel columns, aligned with the webs parallel, a distance of $1.1 \mathrm{~m}(3.5 \mathrm{ft})$ apart as illustrated in Figure 1. Each tower column is fabricated from four wide-flange structural steel sections (W10x33) spliced together. The two columns are framed to an existing building column with 8 "stand-offs", fabricated from $3.1 \mathrm{~m}$ $(10 \mathrm{ft})$ W6x20 wide-flange sections. Stand-offs are nominally spaced every $2.4 \mathrm{~m}(8 \mathrm{ft})$ along the column height. At the base, column flanges are bolted to heavy steel angles $(\angle 5 \times 3-1 / 2 \times 3 / 8)$ which are in turn bolted to a $0.61 \mathrm{~m}$ by $1.83 \mathrm{~m}$ ( 2 by $6 \mathrm{ft}$ ) steel plate. Prior to erection of the tower the base plate-angle assembly was leveled and grouted to provide for a uniform bearing surface. The base plate is secured with 6 through-bolts to anchors in the laboratory floor.

The drop tower was designed to be adjustable to allow for impact sleds of various widths. To allow for adjustment in width, the stand-offs and base plate angles have holes drilled every $0.15 \mathrm{~m}$ (6 in), to which the tower columns are bolted. The column nearest the building wall is intended to remain stationary, while the other column is positioned to the desired width using the laboratory 30 -ton overhead crane. 

Access to any elevation of the tower is provided by a steel rung ladder which is bolted to the stand-off beams. A fall arresting safety cable is mounted at the top of the access ladder.

\section{$\underline{\text { Erection }}$}

Assembly of the tower was carefully planned and carried out in phases. The tower was first assembled on the laboratory floor in 4 major pieces, each piece comprised of 2 column sections, 2 stand-offs and the access ladder, bolted together to form an " $\mathrm{H}$ " section. The 4 major pieces were then placed end-to-end on the laboratory floor, as they would be when erected, and loosely bolted together to check the fit of each connection. Adjustments were made at this point to correct for fabrication errors and misalignment of bolt holes. Erection of the tower began by lifting the first $\mathrm{H}$ section into place using a fork lift. The base section was then leveled and grouted, bolted to the building column, and anchored to the floor. The three remaining $\mathrm{H}$ sections were lifted into place using a 28-ton mobile crane, spliced to the section below and bolted to the building column. A $30.5 \mathrm{~m} \mathrm{(100} \mathrm{ft)} \mathrm{man-lift} \mathrm{was} \mathrm{used} \mathrm{to} \mathrm{gain} \mathrm{access} \mathrm{to} \mathrm{the} \mathrm{high}$ elevation connections. Finally, the ladder sections were welded together at the three butt joints.

\subsection{Impact Sled}

The body of the impact sled is an aluminum plate, $0.81 \mathrm{~m}$ wide by $1.27 \mathrm{~m}$ high by 0.64 $\mathrm{cm}$ thick, ( 32 by 50 by 0.25 in), as illustrated in Figure 2. Aluminum angle is bolted along the perimeter, and to each side of the plate, to which are attached the side rails, the tup assembly and other fixtures. The side rails are made of 102 by $152 \mathrm{~mm}$ ( 4 by 6 in) wooden posts, shaped as illustrated in Figure 2 to facilitate mounting of the sled guide-wheels. The top of the side rail is flush with the top of the plate, the bottom extends approximately $254 \mathrm{~mm}$ (10 in) below the bottom of the plate. Four hard rubber wheels, of the type that can be found in most hardware stores, are mounted to each post ( 2 top and 2 bottom). At present the impact sled is configured with the tup assembly shown in Figure 3. The tup is made of aluminum, is semicircular in shape with a radius of $63.5 \mathrm{~mm}(2.5 \mathrm{in})$ and is $305 \mathrm{~mm}$ (12 in) long. The current sled weighs approximately $580 \mathrm{~N}$ (130 lbf).

The sled is dimensioned to provide a "snug" fit when placed in the drop tower, thereby limiting excessive lateral vibration while providing for a smooth vertical drop. The sled must be partially disassembled to install and remove it from the drop tower.

\subsection{Sled Hoist Assembly}

The sled hoist assembly provides the means to raise the sled to any elevation and electronically release it from the ground (Figure 2.). The hoist consists of a $0.76 \mathrm{~m}$ ( $30 \mathrm{in}$ ) cross beam to which are mounted short sections of side rail. Four rubber wheels are mounted on each side rail to guide the cross beam up and down the tower. The cross beam is connected to a cable which runs to the top of the drop tower, over a set of pulleys and down the outside of the tower 


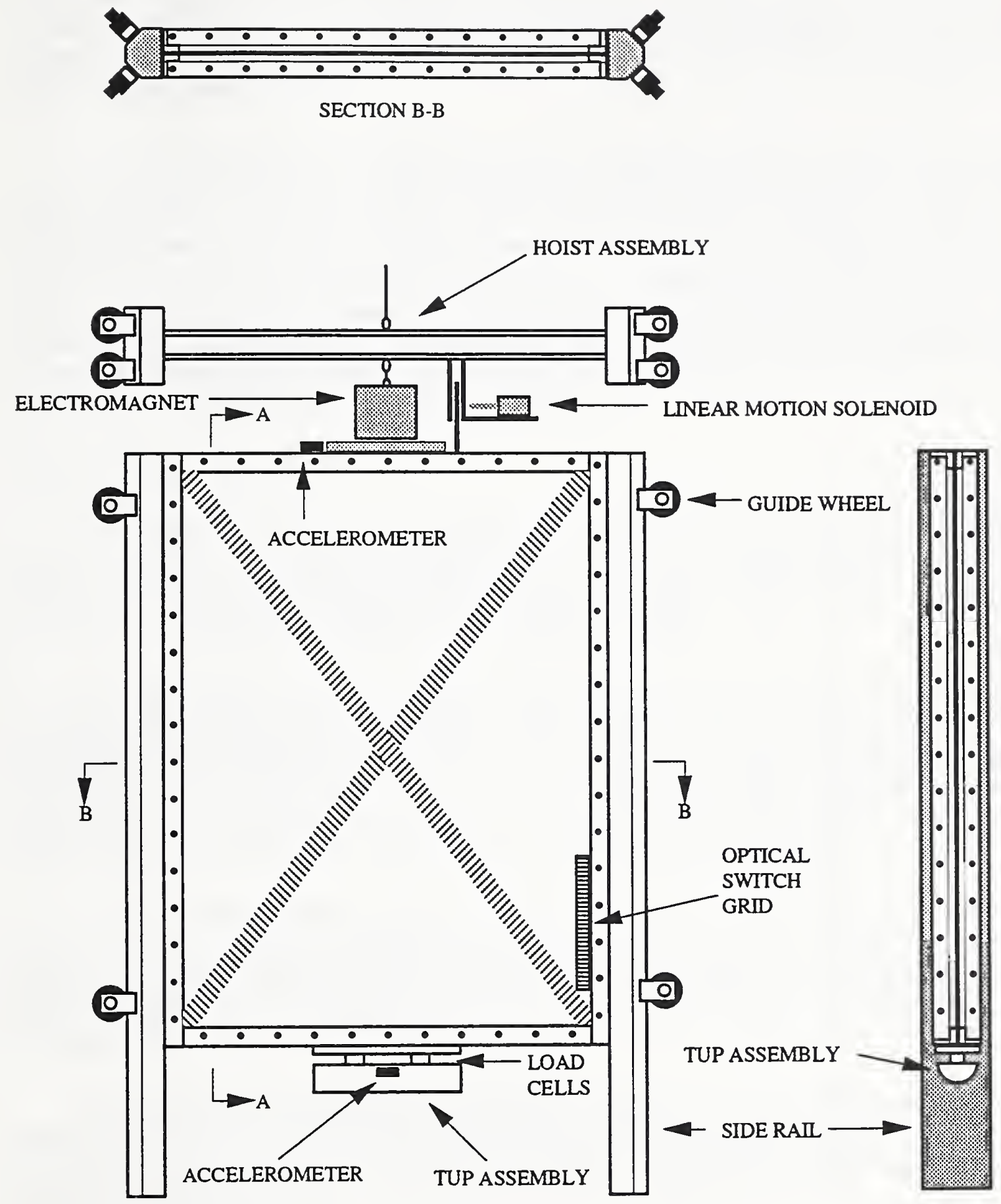

SECTION A-A

FIGURE 2. IMPACT SLED AND SLED HOIST ASSEMBLY 

to an electric winch. Mounted beneath the cross beam is an electromagnet with a load capacity of $1330 \mathrm{~N}(300 \mathrm{lbf})$ and a linear motion pull solenoid. The electromagnet is the primary load carrying link in the hoist system; the solenoid is a backup to prevent accidental release of the sled in case of power failure.

To raise the impact sled, the cross beam is lowered until the electromagnet touchs the top of the sled. Power is than supplied to the electromagnet causing the magnet to "pick-up" the sled by attaching to a small steel plate mounted on top of the sled. At the same time, the linear solenoid is powered, driving the plunger through a hole in a plate which is also mounted on the top of the impact sled (see Figure 2.). The sled is then raised to any elevation via the electric winch. Marks are painted on the side of the drop tower at $0.3 \mathrm{~m}(1 \mathrm{ft})$ intervals to allow for easy positioning of the impact sled. To release the sled, a switch is thrown from ground level, causing the electromagnet to drain and the solenoid plunger to retract. The sled then falls freely under its own weight away from the hoist assembly.

\subsection{Sled Fall Arresting System}

The purpose of the fall arresting system is to stop the impact sled at ground level in as short a distance as possible, while minimizing the arresting load on the sled. For the current sled, this requires dissipating up to $10,600 \mathrm{~N}$-m (7800 ft-lbf) of kinetic energy in less than 1.2 $\mathrm{m}(4 \mathrm{ft})$, as constrained by the height of the specimen holder.

After considering several alternatives, a system was selected which uses deformable foam to dissipate the kinetic energy. A schematic of the arresting system is shown in Figure 3. At the base of each tower column is located a stack of foam, cut to fit tightly between the flanges of the column. The stack includes a thick layer ( $609 \mathrm{~mm}$ [24 in]) of highly crushable foam, a 12.7 $\mathrm{mm}(0.5 \mathrm{in})$ steel plate and a thin layer $(114 \mathrm{~mm}$ [4.5 in]) of elastic foam. The stacks are secured in place to the columns with aluminum angles and fiberglass tape.

When the impact sled is dropped, the side rails, which extend below the sled, strike the stacks of foam causing them to compress and deform. The elastic foam "softens" the impact and reduces the peak arresting force while the crushable foam absorbs most of the impact energy by deforming plastically. The steel plates are placed in the stack to increase the loading area on the crushable foam.

The foam bumpers described are good for a single drop from full height with the current sled, then they must be replaced. When dropping from lower elevations the stacks can be used more than once, but typically for not more than 3 tests. Alternatively, smaller stacks can be used and replaced after each test.

\subsection{Specimen Support Frame}

The specimen support frame is fabricated from 102 by 102 by $9.5 \mathrm{~mm}$ ( 4 by 4 by $3 / 8$ in) structural steel tube, and is nominally $1.22 \mathrm{~m}(4 \mathrm{ft})$ high, $2.03 \mathrm{~m}(6.7 \mathrm{ft})$ wide and $4.72 \mathrm{~m}$ 







(15.5 ft) long. The support frame is illustrated in Figure 3.

The frame has been designed to be adjustable and, as a result, provides great flexibility in design of the test set-up. The frame has 4 pair of legs: 2 pair are permanently welded to the frame, and 2 pair can be moved along the length of the frame and bolted into place. Bolt-on extension legs have been fabricated to provide an additional $410 \mathrm{~mm}$ (16 in) of height. The frame can also be moved relative to the drop tower for correct alignment with the fall line.

An axial compressive or tensile load can be applied to a specimen using a $80 \mathrm{kN}$ ( 9 ton) hydraulic ram mounted to one end of the frame. Fixtures have been fabricated which mount on the frame to provide for simply-supported, clamped and hinged end conditions.

\subsection{Instrumentation and Data Acquisition System}

\section{$\underline{\text { Instrumentation }}$}

The ITF is currently instrumented to measure acceleration of the impact sled, tup load, sled displacement in the early phase of impact and a single specimen reaction load when tested in a simply-supported condition. High-speed movie cameras are available for recording the impact process.

Mounted to the top of the impact sled and in the tup assembly (Figure 2.) are miniature peizoresistive accelerometers, designed specifically for shock and vibration testing. The accelerometers measure $16 \times 16 \times 16 \mathrm{~mm}(0.63 \times 0.63 \times 0.63 \mathrm{in})$, weigh 10 grams $(0.35 \mathrm{oz})$, have a range of $+/-200 \mathrm{~g}$ and an overrange of $+/-10,000 \mathrm{~g}$ (where $\mathrm{g}$ is the acceleration due to gravity).

To measure impact load, two piezoelectric load cells are mounted in the tup assembly as shown in Figure 2. The load cells are compression type devices with a range of $89 \mathrm{kN}$ (20 kip). The instruments measure $28 \mathrm{~mm}$ (1.1 in) in diameter, $10 \mathrm{~mm}(0.43 \mathrm{in})$ in height and weigh 1.3 oz. Two similar load cells are mounted in a fixture, which when summed, measure a single reaction in a simply-supported test configuration.

Mounted to one column of the drop tower is a slotted optical switch. The switch consists of an infrared emitting diode and a phototransistor on opposite sides of a $5.08 \mathrm{~mm}(0.2$ in) wide slot. Mounted to the impact sled, and aligned to pass through the switch slot as the sled passes the point of impact, is a $254 \mathrm{~mm}$ (10 in) translucent grid with a spacing of $2.5 \mathrm{~mm}(0.1 \mathrm{in})$. As the grid passes through the slot the switch reads "on" when the infrared light is unobstructed, and "off" when the light is obstructed by a grid line. Switch "pulses" are recorded by the data acquisition system and are converted to a sled displacement time history. 


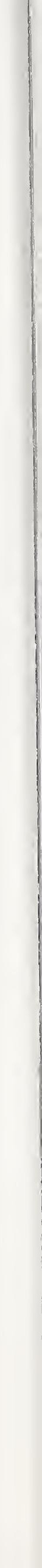




\section{Data Acquisition System}

Data are recorded using a digital data acquisition system. The system has a maximum sampling rate of 250,000 samples per second, gross over all channels (i.e., the maximum sample rate is approximately 25,000 samples per second when scanning 10 channels). The system has 128 channels of simultaneous sample-hold data input, each of which has independently selectable gain settings from 1 to 500 and hardware selectable noise filters. The analog inputs are followed by a multiplexed, programmable gain amplifier (selectable gain from 1 to 8 ) and a 12 bit ADC. With the available pre- and post-gains, channel full scale ranges can be selected from $+/-10 \mathrm{~V}$ to as low as $+/-2.5 \mathrm{mV}$, with corresponding resolutions of $+/-2.5 \mathrm{mV}$ and $+/-.6 \mu \mathrm{V}$. The system is also configured with an 8 channel constant voltage signal conditioning module, a 4 channel analog output module, and a 2 channel timing/frequency counter module.

The interface to the data acquisition system is through a microcomputer and menu-driven software. The control software allows for easy set-up, data acquisition and review of test data. The system can be triggered manually or off of pre-set data values on selectable data channels. Data can be recorded in the system memory, and then later stored permanently on the 300 megabyte hard disk, or recorded directly to the hard disk.

\section{Performance Characteristics}

After the ITF was erected the facility was proof tested. The first series of tests involved repeated free drops to insure that the sled could be safely stopped from any elevation. A series of tests were then performed for the purpose of developing a velocity calibration curve and for estimating the energy loss due to frictional losses in the tower.

To develop the calibration curve the velocity of the impact sled was determined at a point $1.94 \mathrm{~m}(6.35 \mathrm{ft})$ above the floor. Two drops were made from each of the following elevations: $9.1,12.2,15.2$ and $18.3 \mathrm{~m}(30,40,50$ and $60 \mathrm{ft}$, respectively). For each test the calibration velocity was determined using three different approaches ${ }^{1}$ : first, by integration of the recorded sled acceleration; second, by differentiation of a least-squares curve fit to the sled displacement, recorded by the optical switch as the sled passed through the designated point; and third, by computing the velocity using the theoretical expression (neglecting any energy loss due to friction or other means)

$$
V=\sqrt{2 g(H-1.94)}
$$

in which $\mathrm{g}$ is the acceleration due to gravity $\left(9.81 \mathrm{~m} / \mathrm{s}^{2}\right)$ and $\mathrm{H}$ is the drop height above the floor.

${ }^{1}$ Although not considered for development of the calibration curve, the velocity of the sled can also be determined from high speed film. 

Presented in Table 1 are the results of the calibration tests. The average velocity of the 2 drops, determined by each of the three methods is presented for each drop elevation. These results are also plotted in Figure 4.

\begin{tabular}{c|c|c|c}
\hline $\begin{array}{l}\text { Drop Height } \\
\mathrm{m}(\mathrm{ft} .)\end{array}$ & $\begin{array}{l}\text { Velocity from } \\
\text { Integration of Sled } \\
\text { Acceleration } \\
\mathrm{m} / \mathrm{s}(\mathrm{ft} / \mathrm{s})\end{array}$ & $\begin{array}{l}\text { Velocity from } \\
\text { Differentiation of Sled } \\
\text { Displacement } \\
\mathrm{m} / \mathrm{s}(\mathrm{ft} / \mathrm{s})\end{array}$ & $\begin{array}{l}\text { Theoretical Velocity } \\
\mathrm{m} / \mathrm{s}(\mathrm{ft} / \mathrm{s})\end{array}$ \\
\hline $9.1(30)$ & $11.4(37.5)$ & $11.3(36.9)$ & $11.9(39.0)$ \\
$12.2(40)$ & $13.3(43.7)$ & $13.3(43.7)$ & $14.2(46.5)$ \\
$15.2(50)$ & $15.1(49.5)$ & $15.2(50.0)$ & $16.2(53.0)$ \\
$18.3(60)$ & $16.9(55.4)$ & $16.9(55.4)$ & $17.9(58.8)$ \\
\hline
\end{tabular}

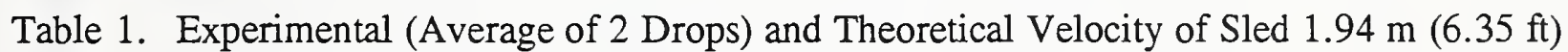
Above Ground Level

Referring to Table 1 and Figure 4, the velocities obtained from the integrated acceleration and the differentiated displacement are consistent. However, the experimental velocities are in every case less than the theoretical, indicating some frictional losses in the tower, which would be expected. A second-order curve has been fit, using a least squares technique, to the average velocity of the two experimental methods at each elevation: this curve is shown as a dashed line in the figure. The equation of this curve is also presented in Figure 4.

Using the average of the experimentally determined velocities and the theoretical velocity, the approximate energy loss per foot of drop has been found to be approximately $68 \mathrm{~N}-\mathrm{m} / \mathrm{m}(15$ $\mathrm{ft}-1 \mathrm{bf} / \mathrm{ft})$. 


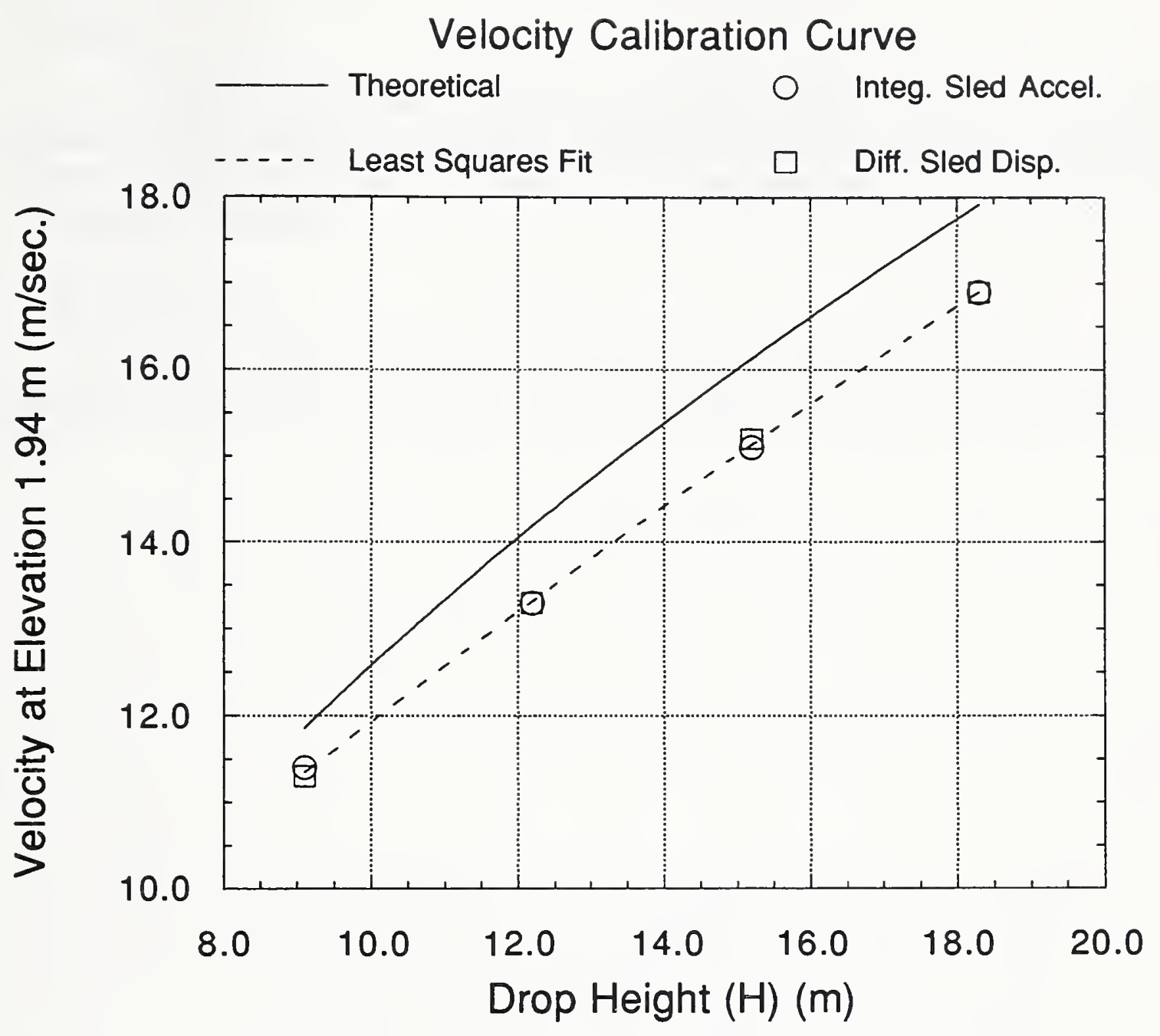

Least Squares Fitted Equation:

Vel $=4.96+.749 H-.00529 H^{2}(\mathrm{~m} / \mathrm{s})$

FIGURE 4. VELOCITY CALIBRATION CURVE 


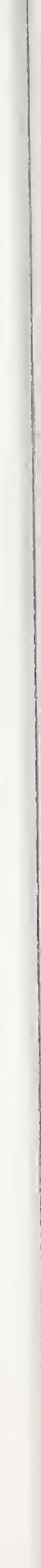




\section{Summary}

The Impact Test Facility is an enhancement to the existing facilities at NIST. The ITF provides for the capability to investigate the behavior of structural elements and systems subject to loads of short duration and high intensity. The constructed facility is versatile and offers a wide operational envelope.

\section{Acknowledgement}

The authors wish to thank Mr. Greg Zamenski for assisting in the proof testing and calibration of the Impact Test Facility, and for developing some of the figures presented in this report. 


\section{Appendix A.}

Presented are a series of photographs which illustrate the ITF under construction, the completed facility and the various components of the system.

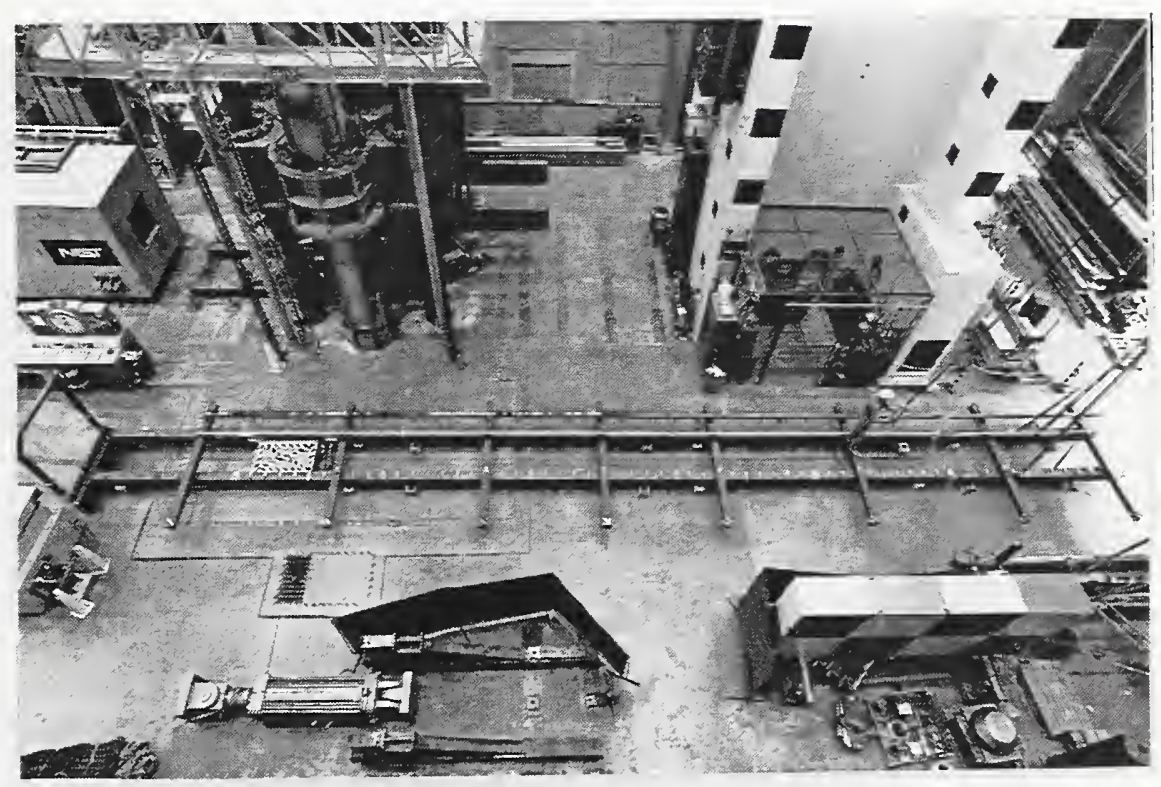

Figure A.1. Drop tower assembled on laboratory floor prior to erection 


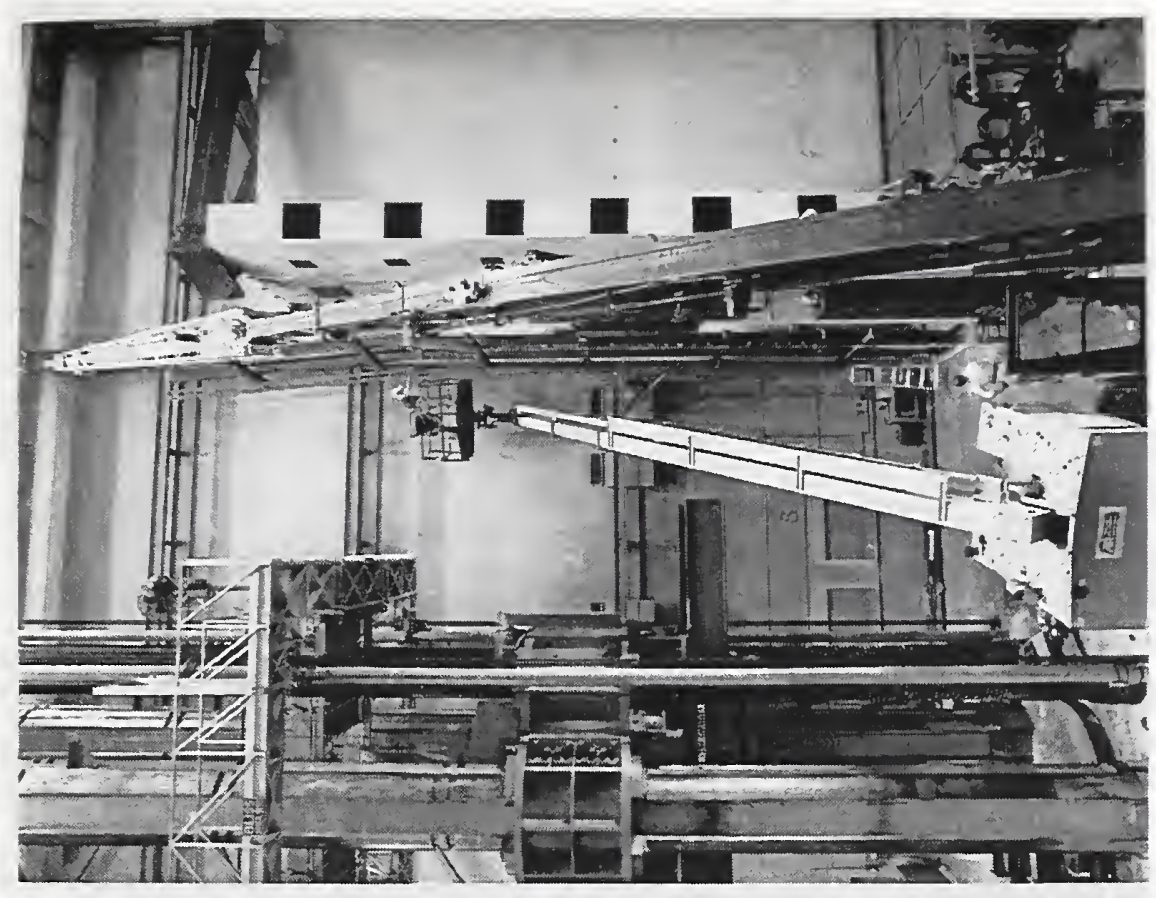

를

䓀

苞

过

os

昜.

ウ

$\stackrel{\Xi}{\Xi}$

诖

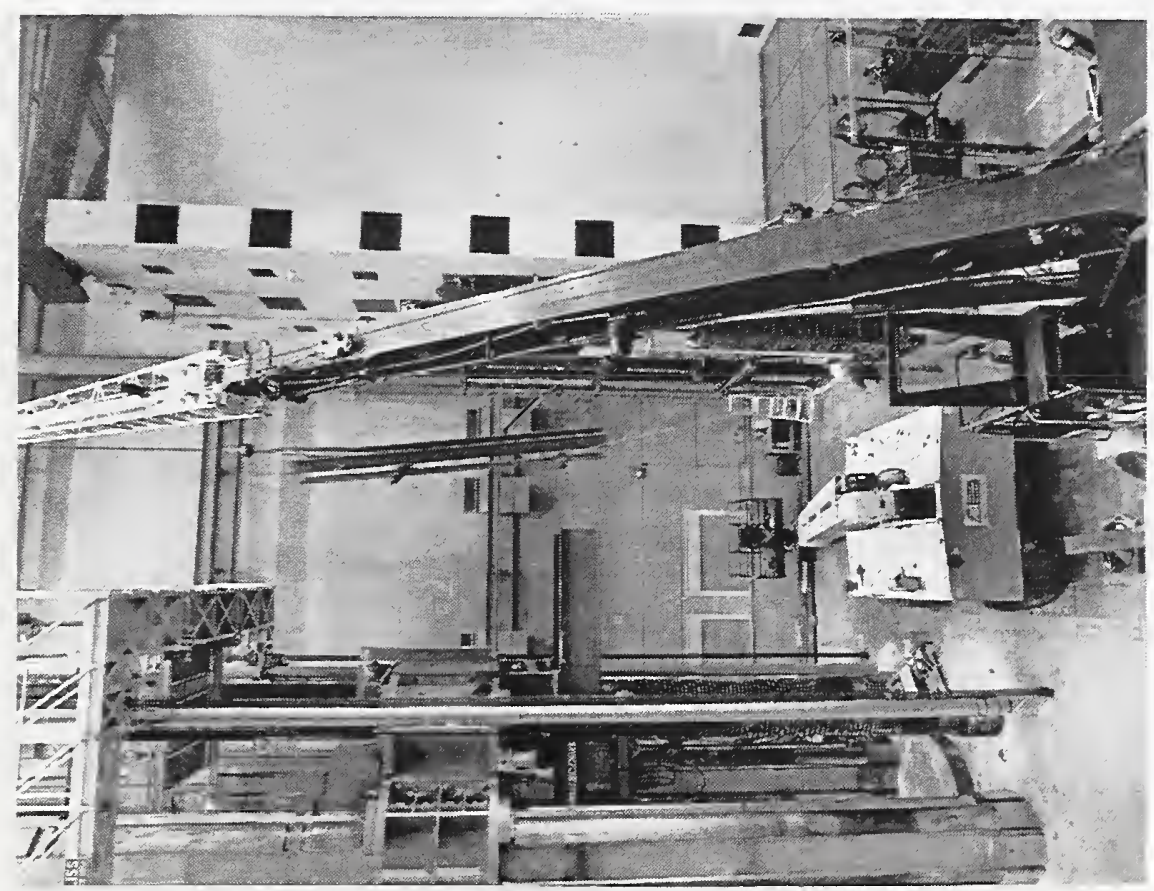

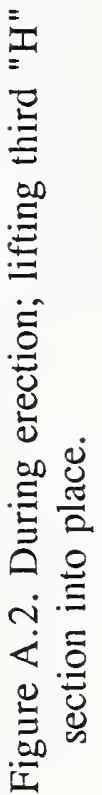




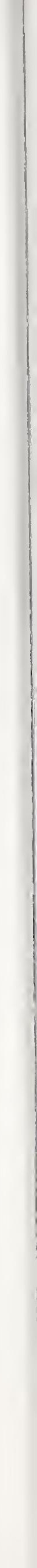






Figure A.4. Drop tower and specimen support frame. 


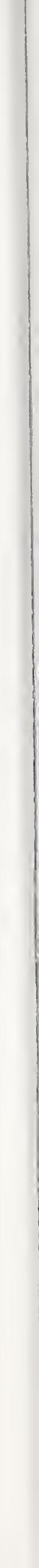




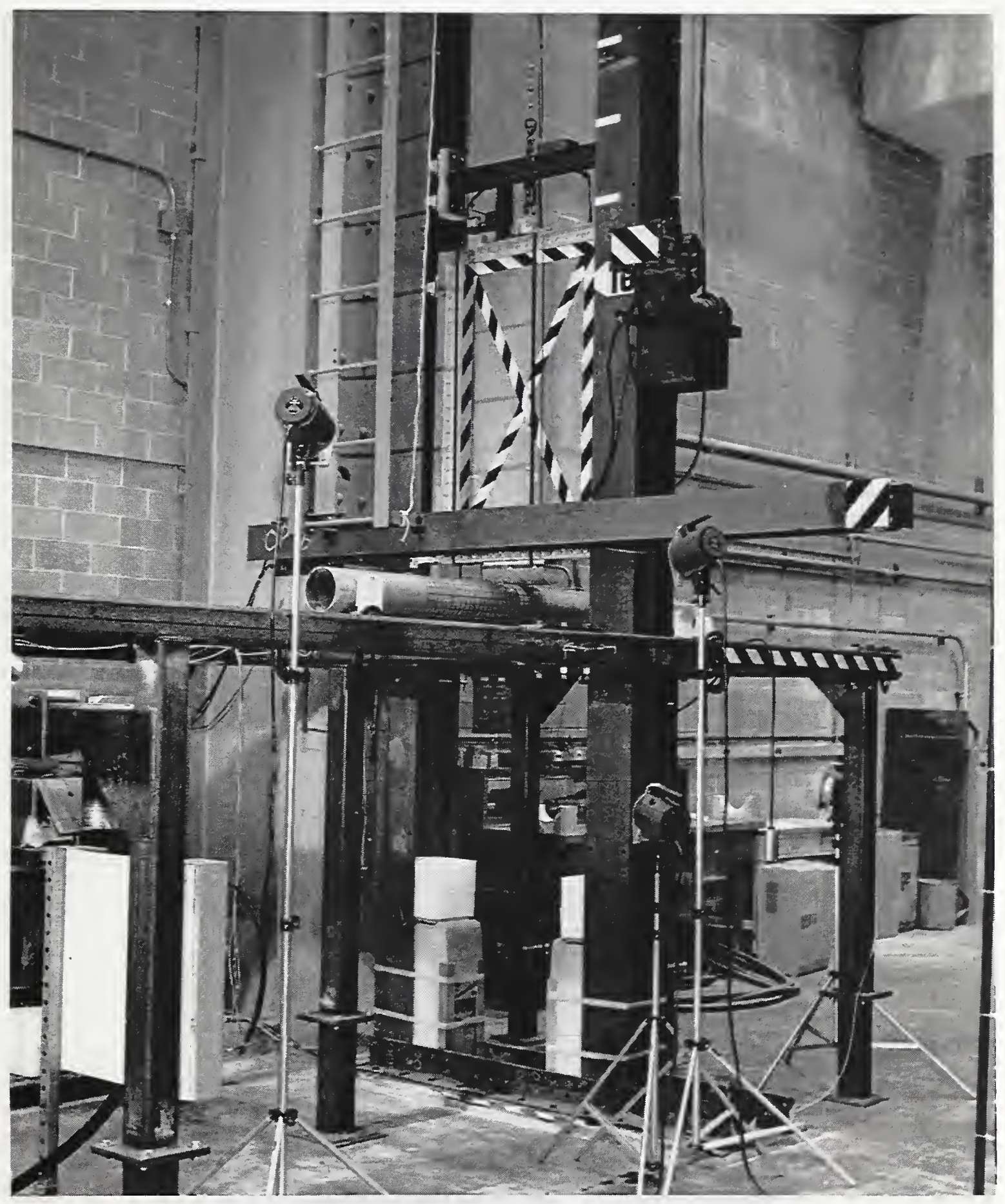

Figure A.5. Drop tower, specimen support frame and impact sled 


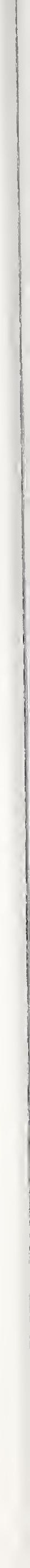




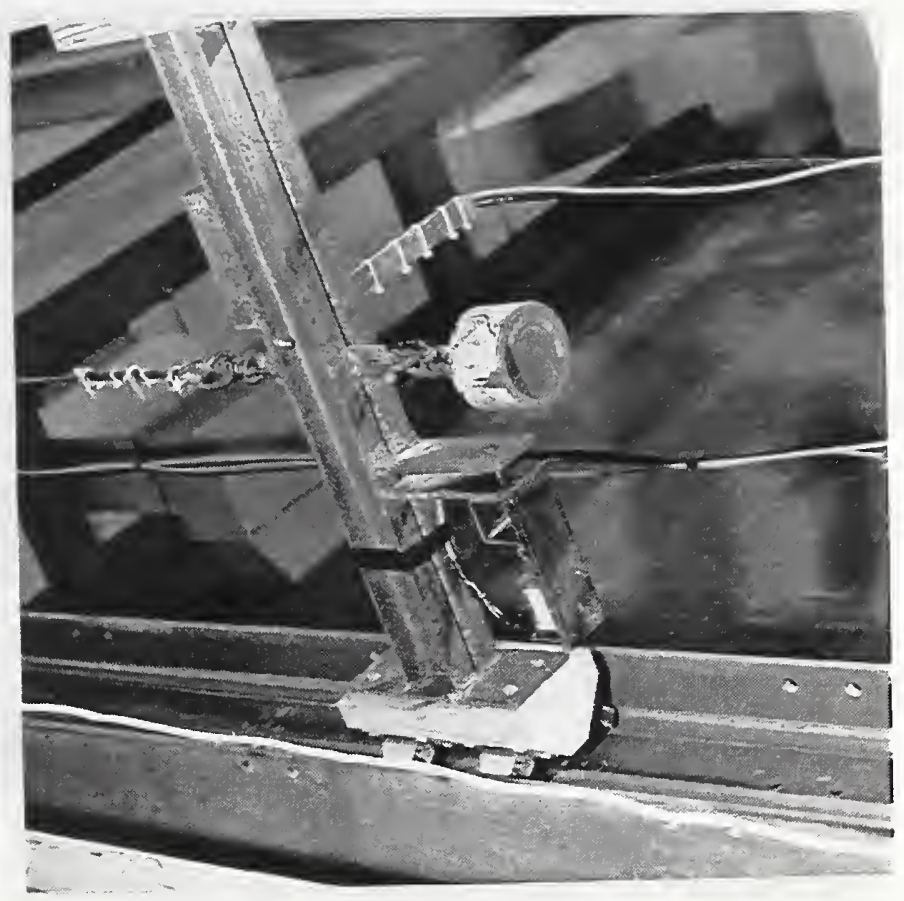

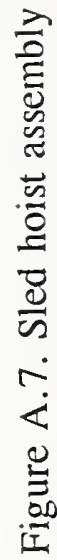



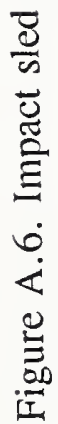




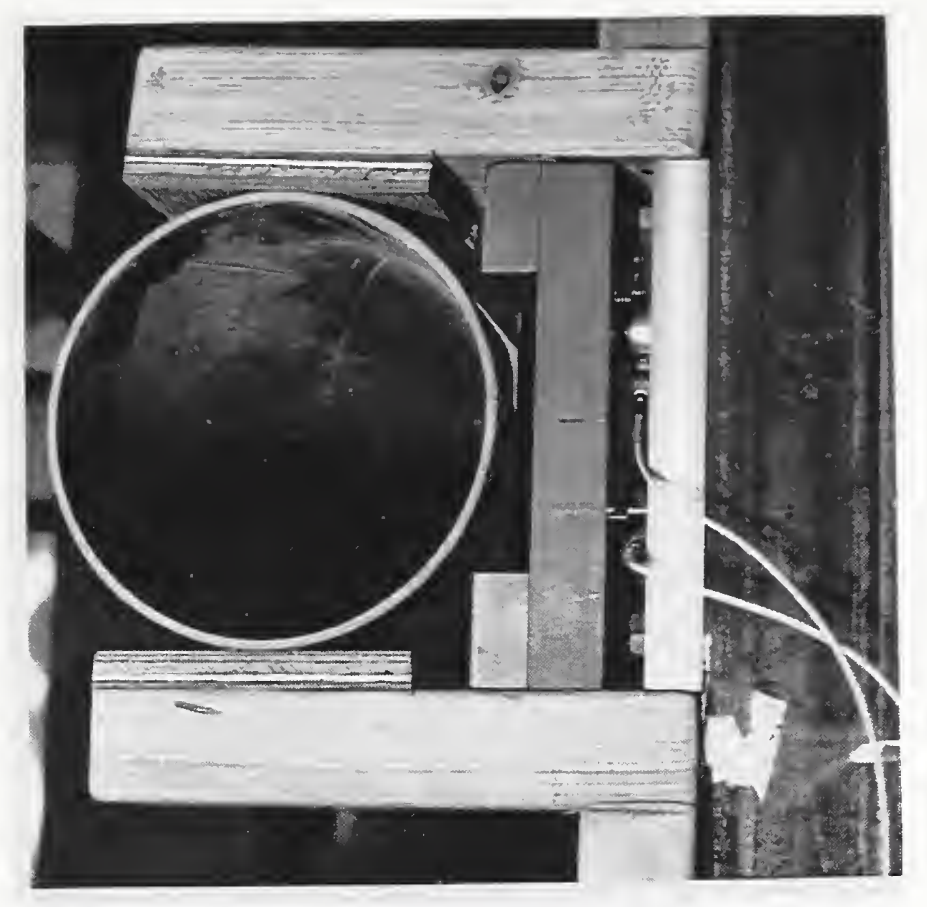

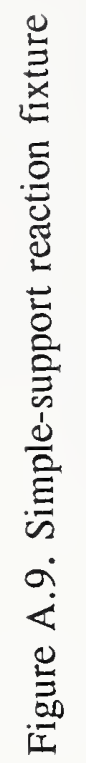



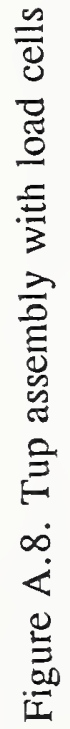




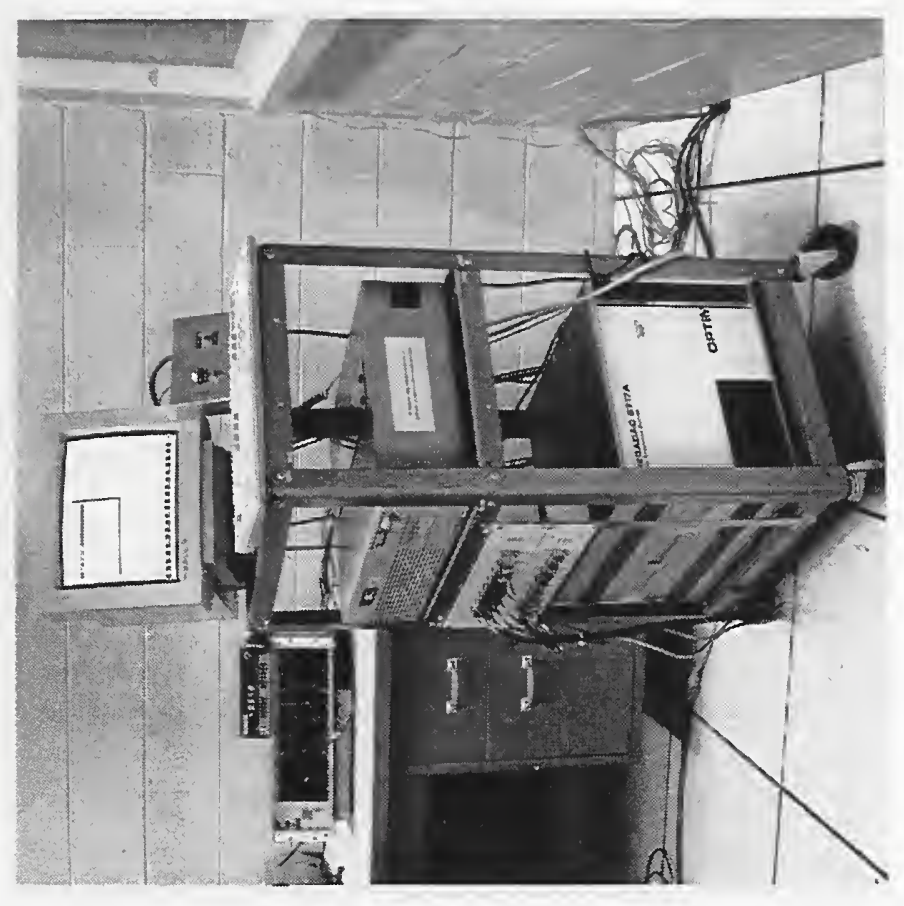

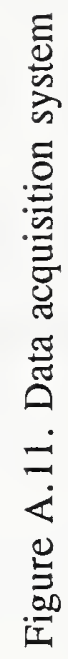

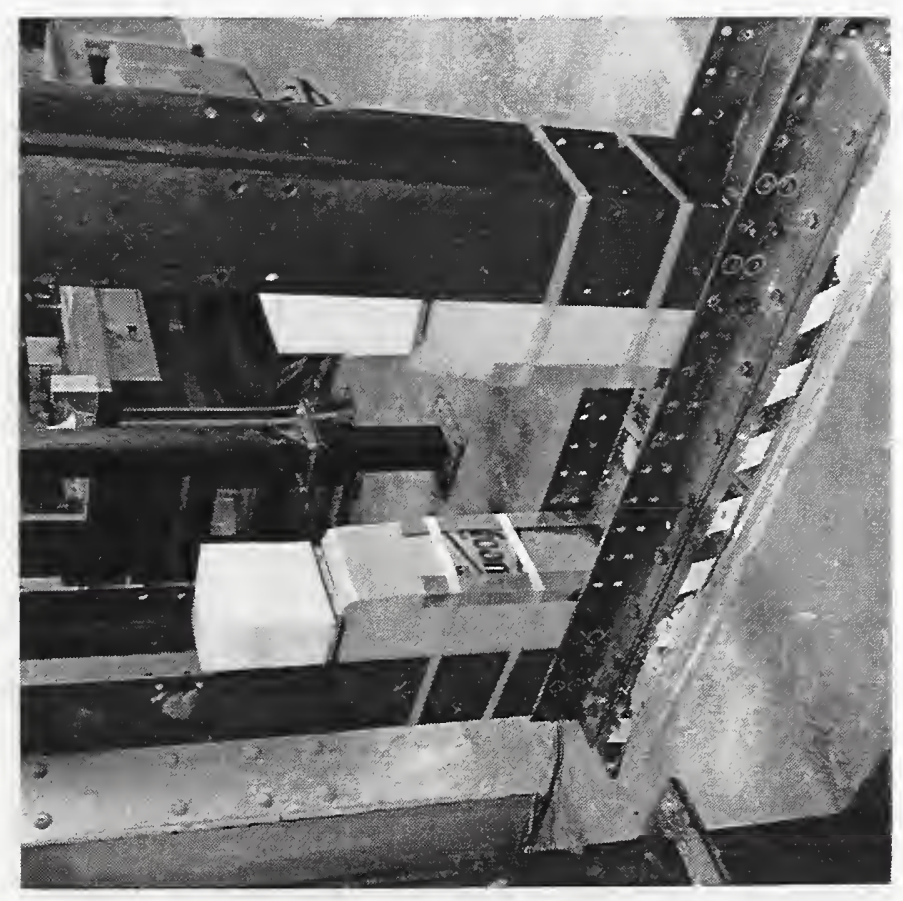

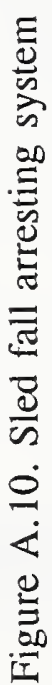












